\title{
Trends in Apolipoprotein B, Non-High-Density Lipoprotein Cholesterol, Low-Density Lipoprotein Cholesterol, and Hemoglobin A1C Among US Adults with Diagnosed Diabetes, 2005-2018
}

XWang ( $\square$ wangxiaes@sdu.edu.cn )

Shandong University Cheeloo College of Medicine

Di Zhu

Shandong University Cheeloo College of Medicine

Yang Du

The University of lowa College of Public Health

\section{Yangbo Sun}

The University of Tennessee Health Science Center

\section{Linda Snetselaar}

The University of lowa College of Public Health

\section{Original investigation}

Keywords: Apolipoprotein B, Diabetes, Non-high-density lipoprotein cholesterol, Low-density lipoprotein cholesterol, Hemoglobin A1c

Posted Date: December 1st, 2020

DOI: https://doi.org/10.21203/rs.3.rs-115413/v1

License: (c) (i) This work is licensed under a Creative Commons Attribution 4.0 International License. Read Full License 


\section{Abstract}

Background: The control of blood glucose and atherogenic cholesterol particle concentrations is fundamental for patients with diabetes. The objective of this study was to examine trends in levels of apolipoprotein B (apo B), non-high-density lipoprotein (non-HDL) cholesterol, low-density lipoprotein (LDL) cholesterol, and hemoglobin A1c (A1C) and changes in the proportion of patients who achieved their glycemic and lipid goals between 2005 and 2018.

Methods: We conducted a serial cross-sectional analysis of the US nationally representative data from the National Health and Nutrition Examination Surveys form 2005 through 2018.

Results: In total, 5536 adults aged 20 years or older with diabetes were included (weighted mean age, 60.2 years; female, $50.1 \%)$. Among all adults with diabetes, the age-adjusted mean apo B levels did not decrease significantly from 2005 to $2016(P=0.077)$. The age-adjusted mean non-HDL cholesterol levels reduced significantly $(P=0.004)$ from 2005 to 2018 . In $2017-2018,55.3 \%$ of patients achieved the A1C goal of $<7 \%$ and $43.8 \%$ achieved the non-HDL cholesterol goal of $<130 \mathrm{mg} / \mathrm{dl}$. In 2015-2016, 47.3\% achieved the apo B goal of $<90 \mathrm{mg} / \mathrm{dL}, 57.2 \%$ achieved the LDL cholesterol goal of $<100 \mathrm{mg} / \mathrm{dl}$, while $30.6 \%$ achieved all four glycemic and lipid goals. The success rates for achieving the goals of apo B, non-HDL cholesterol, and LDL cholesterol were higher in older compared with younger subjects, while white patients exhibited better glycemic control than Mexican Americans and non-Hispanic black patients.

Conclusion: Among adults with diabetes, there was a significant reduction in non-HDL cholesterol level while there was no change in levels of apo B, LDL cholesterol or A1C over the past decade. Nevertheless, large percentages of adults with diabetes continue to have higher levels of apo B, non-HDL cholesterol, LDL cholesterol, and A1C.

\section{Introduction}

Diabetes is associated with an increased risk of cardiovascular disease, which remains the primary cause of morbidity and mortality among individuals with both type 1 and type 2 diabetes [1]. To prevent microvascular complications and macrovascular disease in individuals with diabetes, the control of blood glucose and atherogenic cholesterol particle concentrations is fundamental for patients with diabetes. In particular, early intensive management of dyslipidemia is warranted to decrease the significant risk of atherosclerotic cardiovascular disease in patients with diabetes.

There is emerging evidence of the importance of monitoring apolipoprotein levels for the management of dyslipidemia [2-6]. Apo B has repeatedly been shown to be superior to low-density lipoprotein (LDL) cholesterol in identifying the risk of cardiovascular disease events [7]. Particularly for individuals with hypertriglyceridemia, the measurement of apo B may be the most clinically useful since it is a direct measure of the total number of circulating atherogenic lipoprotein particles. By contrast, calculated LDL cholesterol values is systematically underestimated when triglyceride levels range from 1.5 to $4.5 \mathrm{mmol} / \mathrm{L}$ and cannot be assessed reliably at all when triglyceride levels are above $4.5 \mathrm{mmol} / \mathrm{L}$. Alternatively, some studies have suggested the use of non-high-density lipoprotein (non-HDL) cholesterol rather than LDL 
cholesterol to enhance risk prediction, particularly in patients with elevated triglyceride levels $[8,9]$. The concentration of non-HDL cholesterol reflects the total cholesterol content of all atherogenic lipoproteins [10] and thus can provide another method for evaluating the risks of atherogenic lipoproteins.

The guidelines updated in 2017 provides recommendations for lowering cholesterol in patients with diabetes [11]. Patients with diabetes are recommended to achieve goals of apo B, non-HDL cholesterol, and LDL cholesterol levels, based on the risk stratification. Similar recommendations also have also been made by the American Association of Clinical Endocrinologists [12]. For individuals with diabetes with no other risk factors, the recommended goals are LDL cholesterol $<100 \mathrm{mg} / \mathrm{dL}$, non-HDL cholesterol $<130 \mathrm{mg} / \mathrm{dL}$, and apo $B<90 \mathrm{mg} / \mathrm{dL}[11,12]$. For individuals with diabetes at very high risk [i.e., patients with one or more risk factor(s)], the recommended goals are LDL cholesterol $<70 \mathrm{mg} / \mathrm{dL}$, non-HDL cholesterol $<100 \mathrm{mg} / \mathrm{dL}$, and apo $\mathrm{B}<80 \mathrm{mg} / \mathrm{dL}$.

However, most previous research has focused only on the achievement of LDL cholesterol goals in individuals with diabetes [13]. One study examined levels of apo B, but only in two survey circles from 2005 to 2008 [14], and another, by Carroll et al., focused only on the mean levels of apo B, non-HDL cholesterol, and LDL cholesterol from 2005 to 2014, and only among adults over the age of 60 [15]. However, diabetes is becoming increasingly common in young and middle-aged adults. Further, few data exist on whether individuals with diagnosed diabetes achieved apo B, non-HDL cholesterol, and LDL cholesterol goals per the updated guidelines.

Despite the controversies, hemoglobin $A_{1 c}(A 1 C)$ still serves as an indispensable index of long-term glycemic control and a reliable indicator of the development of long-term complications in diabetic patients $[16,17]$. Achievement of the $A 1 C$ target concentration of $<7 \%$ has been demonstrated to decrease the microvascular complications of type 1 and type 2 diabetes [18]. However, previous studies have found that many patients with diabetes are not achieving their recommended A1C goals [19], and poor glycemic control has been common among patients in general [20]. The significant changes in the treatments and interventions used for diabetes over the past decade, a fresh assessment of trends in the glucose and lipid control of individuals with diabetes is necessary by using the latest available representative data.

Therefore, the purpose of the present study was to analyze trends in the mean concentrations of serum apo $B$, non-HDL cholesterol, and LDL cholesterol, and A1C in US adults with diagnosed diabetes from 20052006 to 2017-2018. In addition, we evaluated changes in the proportion of individuals who achieved the LDL cholesterol, non-HDL cholesterol, and apo B goals, and assessed trends in the glycemic control achieved by US adults with diagnosed diabetes from 2005 to 2018.

\section{Methods}

This study was based on cross-sectional data from the National Health and Nutrition Examination Survey (NHANES), which has been a nationally representative surveys of the noninstitutionalized US population since 1999 [21]. Each of the NHANES survey uses a complex, multistage, and stratified sampling design. The study protocol of NHANES was approved by the research ethics review board of the National Center for 
Health Statistics (NCHS) of the Centers for Disease Control and Prevention (CDC). Written informed consent was provided from all of the participants. The study design, data collection methods, and protocol for the survey have been previously reported [22].

Each NHANES survey included in-home interviews, mobile examinations, and laboratory measures. The inhome interviews gathered basic demographic and health information about the participants. They were then scheduled to participate in a mobile examination center for the physical examinations and laboratory tests.

\section{Study Participants}

The study population included adults aged 20 years or older who reported a diagnosis of diabetes. The diabetes section in the NHANES survey included personal interview data regarding diabetes, which were asked in the home by trained interviewers. The participants were asked whether they had ever been told by a health professional that they had diabetes or sugar diabetes. Those who answered "yes" were considered to have a diagnosis of diabetes. We excluded women who reported diagnosed diabetes during pregnancy. Based on the information that participants reported about race/ethnicity, participants were categorized by the NCHS (Mexican American, non-Hispanic white, non-Hispanic black, other Hispanic, or other). Other Hispanic and other were combined to create other racial/ethnic groups in the present study.

\section{Survey Years}

We accessed data from 2005-2006 through 2017-2018, thereby including all 7 continuous NHANES data cycles. We analyzed all of the available NHANES cycles for A1C (2005-2018), total cholesterol (20052018), HDL cholesterol (2005-2018), LDL cholesterol (2005-2016), and apo B (2005-2016). The data analysis was conducted in the United States from January to July 2020. In cases in which the relevant variables were missing, those individuals were excluded from particular analyses, and all available data were analyzed in this study.

\section{Laboratory Methods}

Serum specimens were collected, processed, and stored under appropriate frozen $\left(-30^{\circ} \mathrm{C}\right)$ conditions until they are shipped for testing. $\mathrm{A} 1 \mathrm{C}$ was measured in a full sample with instruments certified by the National Glycohemoglobin Standardization Program and standardized according to the reference methods of the Diabetes Control and Complications Trial. Several changes were made to the methods for measuring serum lipids and the A1C over the 14-years of data collection from 2005 to 2018; the details are available from the NHANES laboratory data documentations [23]. Serum total cholesterol, HDL cholesterol, triglycerides, and apo $B$ values were measured directly and standardized according to the CDC's criteria of the lipid standardization program [24]. Non-HDL cholesterol levels were calculated as the difference between the levels of total cholesterol and HDL cholesterol. For serum samples with triglyceride levels of $400 \mathrm{mg} / \mathrm{dL}$ or 
lower, the levels of LDL cholesterol were calculated for individuals who had fasted properly ( $\geq 8$ to $<24 \mathrm{~h}$ ) using the Friedewald equation [25]. Serum samples with triglyceride levels greater than $400 \mathrm{mg} / \mathrm{dL}$ were set as missing. For the patients with diagnosed diabetes, glycemic management was evaluated primarily based on the $\mathrm{A} 1 \mathrm{C}$ measurement.

\section{Outcome Assessment}

The primary outcome measures were trends in mean concentrations of serum apo B, non-HDL cholesterol, and LDL cholesterol among US adults with diagnosed diabetes from 2005-2006 to 2017-2018. Additional outcome measures included changes in the percentages of patients who achieved an apo B goal of < $90 \mathrm{mg} / \mathrm{dl}$, a non-HDL cholesterol goal of $<130 \mathrm{mg} / \mathrm{dl}$, and an LDL cholesterol goal of $<100 \mathrm{mg} / \mathrm{dl}$ between 2005 and 2018. We also observed the percentages of patients who were achieving the more aggressive alllipid goals (i.e., LDL-C targets of $<70 \mathrm{mg} / \mathrm{dL}$, non-HDL-C targets of $<100 \mathrm{mg} / \mathrm{dL}$, and apo $B$ targets of $<$ $80 \mathrm{mg} / \mathrm{dL}$ ) at the end of the study period. Lastly, we evaluated changes in the levels of glycemic control achieved among U.S. adults with diagnosed diabetes between 2005 and 2018.

\section{Statistical analysis}

To obtain nationally representative estimates, the sample weights, clustering and stratification of the NHANES survey were incorporated into all of the analyses. The arithmetic means for non-HDL cholesterol and apo $B$ and the percentage of participants who achieved the apo B, non-HDL cholesterol levels, and A1C goals are presented. Because of the skewed distribution of $A 1 C$, the geometric mean, calculated by back transforming the mean of the logarithm of the $\mathrm{A} 1 \mathrm{C}$ concentration values, is presented. The means and percentages for adults with diabetes were age-adjusted, using the direct method to the projected 2000 U.S. Census population estimates [26].

For the primary analyses, the means and proportions were calculated by sex, age, and race/ethnicity strata, adjusting for age. We used multivariable linear regression, adjusting for age and race/ethnicity to examine trends by regarding the 2-year survey cycle as a continuous variable, and so regression coefficients $(\beta)$ could be reported per one year. Trends in A1C concentrations were estimated using log-transformed values because of the skewed distribution for A1C. We used the survey procedures in SAS version 9.3 software (SAS Institute Inc) to account for the complex design. For all of the analyses, the statistical hypotheses were tested using an a level of 0.05 based on a 2-tailed test.

\section{Results}

\section{Analytic Sample}

A total of 5536 adults aged 20 years or older who reported a diagnosis of diabetes participated in an NHANES examination from 2005 to 2018 and were eligible for inclusion in the present study (weighted mean age, 60.2 years, standard error $[S E] \pm 0.27$; female, $50.1 \%$ ) (Table 1 ). Because the data relating to apo 
B, non-HDL cholesterol level, LDL cholesterol, and/ or A1C were missing for some participants; therefore, the sample sizes vary slightly among these outcomes. LDL levels were calculated using the Friedewald formula. To calculate LDL cholesterol values by the formula, participants were excluded for whom total cholesterol or HDL cholesterol data were unavailable or whose triglyceride levels exceeded $400 \mathrm{mg} / \mathrm{dL}$. More than half of the subjects had been told that they had diabetes for the first time when they were aged 40 to 59 years, while nearly one in five of the subjects was between aged 20 and 39 years. 
Table 1

Sociodemographic characteristics of US adults with diabetes by NHANES survey cycle, 2005 to 2018 Characteristics No. of Participants (Weighted \%) *

$\begin{array}{llllllll}2005- & 2007- & 2009- & 2011- & 2013- & 2015- & 2017- & \text { Overall } \\ 2006 & 2008 & 2010 & 2012 & 2014 & 2016 & 2018 & \\ (\mathrm{n}= & (\mathrm{n}= & (\mathrm{n}= & (\mathrm{n}= & (\mathrm{n}= & (\mathrm{n}= & (\mathrm{n}= & (\mathrm{n}= \\ 513) & 782) & 775) & 720) & 764) & 881) & 921) & 5356)\end{array}$

Age group, $y+$

\begin{tabular}{lllllllll}
\hline 20-39 & 36 & 54 & 40 & 44 & 40 & 66 & 40 & 320 \\
& $(10.2)$ & $(9.3)$ & $(7.1)$ & $(6.5)$ & $(6.5)$ & $(9.3)$ & $(7.1)$ & $(7.9)$ \\
\hline $40-59$ & 152 & 226 & 221 & 230 & 256 & 257 & 238 & 1580 \\
& $(39.7)$ & $(39.4)$ & $(36.6)$ & $(38.8)$ & $(39.1)$ & $(33.4)$ & $(33.6)$ & $(36.8)$ \\
\hline$\geq 60$ & 313 & 483 & 497 & 441 & 451 & 545 & 626 & 3356 \\
& $(50.2)$ & $(51.4)$ & $(56.3)$ & $(54.7)$ & $(54.3)$ & $(57.3)$ & $(59.3)$ & $(55.3)$ \\
Sex & & & & & & & & \\
Male & 243 & 384 & 389 & 367 & 367 & 459 & 491 & 2700 \\
& $(43.9)$ & $(47.7)$ & $(50.4)$ & $(49.1)$ & $(48.4)$ & $(53.2)$ & $(53.4)$ & $(49.9)$ \\
Female & 270 & 398 & 386 & 353 & 397 & 422 & 430 & 2656 \\
& $(56.1)$ & $(52.3)$ & $(49.6)$ & $(50.9)$ & $(51.6)$ & $(46.8)$ & $(46.6)$ & $(50.1)$ \\
Race/ethnicity & & & & & & & & \\
Mexican American & 113 & 133 & 164 & 76 & 131 & 201 & 142 & 960 \\
& $(8.6)$ & $(7.7)$ & $(9.6)$ & $(8.2)$ & $(9.9)$ & $(11.3)$ & $(9.3)$ & $(9.4)$ \\
Non-Hispanic white & 193 & 309 & 284 & 224 & 277 & 232 & 307 & 1826 \\
& $(61.5)$ & $(63.8)$ & $(58.8)$ & $(59.3)$ & $(62.5)$ & $(57.7)$ & $(61.6)$ & $(60.7)$ \\
Non-Hispanic black & 171 & 229 & 190 & 253 & 195 & 205 & 211 & 1454 \\
& $(18.4)$ & $(18.1)$ & $(17.2)$ & $(16.9)$ & $(14.7)$ & $(14.3)$ & $(11.3)$ & $(15.4)$ \\
\hline Otherf & 36 & 111 & 137 & 167 & 161 & 243 & 261 & 1116 \\
& $(11.5)$ & $(10.4)$ & $(14.4)$ & $(15.6)$ & $(12.8)$ & $(16.8)$ & $(17.8)$ & $(14.6)$ \\
\hline
\end{tabular}

\section{Education level}

$\begin{array}{lllllllll}\text { Less than high school } & 198 & 332 & 303 & 254 & 229 & 282 & 241 & 1839 \\ & (27.1) & (30.4) & (29.4) & (25.5) & (20.9) & (20.6) & (15.8) & (23.4) \\ \text { High school } & 128 & 180 & 152 & 154 & 181 & 189 & 212 & 1196 \\ & (27.3) & (25.9) & (20.1) & (26.3) & (24.2) & (21.1) & (29.4) & (24.9) \\ \text { More than high school } & 187 & 270 & 320 & 312 & 354 & 410 & 468 & 2321 \\ & (45.6) & (43.7) & (50.5) & (48.2) & (54.9) & (58.3) & (54.8) & (51.7)\end{array}$


Table 2

Age-adjusted percentage of achieving apo $\mathrm{B}<90 \mathrm{mg} / \mathrm{dL}$ among U.S. adults with diabetes aged $\geq 20$ years, 2005-2016

\begin{tabular}{|c|c|c|c|c|c|c|c|}
\hline & $\begin{array}{l}2005- \\
2006\end{array}$ & $\begin{array}{l}2007- \\
2008\end{array}$ & $\begin{array}{l}2009- \\
2010\end{array}$ & $\begin{array}{l}2011- \\
2012\end{array}$ & $\begin{array}{l}2013- \\
2014\end{array}$ & $\begin{array}{l}2015- \\
2016\end{array}$ & \multirow{2}{*}{$\begin{array}{l}P \text { for } \\
\text { linear } \\
\text { trend }\end{array}$} \\
\hline & $\begin{array}{l}\text { apo B< } \\
90 \mathrm{mg} / \mathrm{dL}\end{array}$ & $\begin{array}{l}\text { apo B< } \\
90 \mathrm{mg} / \mathrm{dL}\end{array}$ & $\begin{array}{l}\text { apo B< } \\
90 \mathrm{mg} / \mathrm{dL}\end{array}$ & $\begin{array}{l}\text { apo B< } \\
90 \mathrm{mg} / \mathrm{dL}\end{array}$ & $\begin{array}{l}\text { apo B< } \\
90 \mathrm{mg} / \mathrm{dL}\end{array}$ & $\begin{array}{l}\text { apo B< } \\
90 \mathrm{mg} / \mathrm{dL}\end{array}$ & \\
\hline Total & $\begin{array}{l}28.8 \\
(20.0 \text { to } \\
37.6)\end{array}$ & $\begin{array}{l}51.0 \\
(32.9 \text { to } \\
69.1)\end{array}$ & $\begin{array}{l}53.7 \\
(37.1 \text { to } \\
70.3)\end{array}$ & $\begin{array}{l}42.4 \\
(30.6 \text { to } \\
54.2)\end{array}$ & $\begin{array}{l}50.1 \\
(36.4 \text { to } \\
63.9)\end{array}$ & $\begin{array}{l}47.3 \\
(33.7 \text { to } \\
60.8)\end{array}$ & 0.184 \\
\hline \multicolumn{8}{|l|}{ Age group, y } \\
\hline $20-39$ & $\begin{array}{l}10.1 \\
(-12.2 \text { to } \\
32.5)\end{array}$ & $\begin{array}{l}44.9(4.5 \\
\text { to } 85.2)\end{array}$ & $\begin{array}{l}55.5 \\
(19.7 \text { to } \\
91.3)\end{array}$ & $\begin{array}{l}38.3 \\
(12.5 \text { to } \\
64.0)\end{array}$ & $\begin{array}{l}48.5 \\
(20.2 \text { to } \\
76.8)\end{array}$ & $\begin{array}{l}43.5 \\
(16.4 \text { to } \\
70.7)\end{array}$ & 0.044 \\
\hline $40-59$ & $\begin{array}{l}40.3 \\
(29.8 \text { to } \\
50.8)\end{array}$ & $\begin{array}{l}46.5 \\
(31.8 \text { to } \\
61.3)\end{array}$ & $\begin{array}{l}47.4 \\
(31.3 \text { to } \\
63.6)\end{array}$ & $\begin{array}{l}33.2 \\
(22.3 \text { to } \\
44.1)\end{array}$ & $\begin{array}{l}47.9 \\
(38.4 \text { to } \\
57.3)\end{array}$ & $\begin{array}{l}44.8 \\
(32.7 \text { to } \\
56.9)\end{array}$ & 0.490 \\
\hline$\geq 60$ & $\begin{array}{l}42.8 \\
(34.9 \text { to } \\
50.7)\end{array}$ & $\begin{array}{l}68.9 \\
(62.7 \text { to } \\
75.0)\end{array}$ & $\begin{array}{l}60.7 \\
(54.9 \text { to } \\
66.4)\end{array}$ & $\begin{array}{l}64.3 \\
(50.6 \text { to } \\
77.9)\end{array}$ & $\begin{array}{l}56.5 \\
(50.1 \text { to } \\
62.9)\end{array}$ & $\begin{array}{l}57.6 \\
(47.2 \text { to } \\
67.9)\end{array}$ & 0.559 \\
\hline \multicolumn{8}{|l|}{ Sex } \\
\hline Male & $\begin{array}{l}39.5 \\
(21.1 \text { to } \\
57.9)\end{array}$ & $\begin{array}{l}65.3 \\
(47.8 \text { to } \\
82.7)\end{array}$ & $\begin{array}{l}61.2 \\
(43.3 \text { to } \\
79.1)\end{array}$ & $\begin{array}{l}57.0 \\
(43.7 \text { to } \\
70.2)\end{array}$ & $\begin{array}{l}75.5 \\
(70.9 \text { to } \\
80.1)\end{array}$ & $\begin{array}{l}51.1 \\
(28.1 \text { to } \\
74.2)\end{array}$ & 0.995 \\
\hline Female & $\begin{array}{l}21.7 \\
(14.8 \text { to } \\
28.6)\end{array}$ & $\begin{array}{l}34.8 \\
(25.9 \text { to } \\
43.7)\end{array}$ & $\begin{array}{l}31.5 \\
(22.4 \text { to } \\
40.5)\end{array}$ & $\begin{array}{l}29.5 \\
(18.3 \text { to } \\
40.7)\end{array}$ & $\begin{array}{l}41.1 \\
(23.6 \text { to } \\
58.6)\end{array}$ & $\begin{array}{l}43.2 \\
(29.3 \text { to } \\
57.2)\end{array}$ & 0.044 \\
\hline \multicolumn{8}{|l|}{ Race/ethnicity } \\
\hline $\begin{array}{l}\text { Mexican } \\
\text { American }\end{array}$ & $\begin{array}{l}20.6(8.8 \\
\text { to } 32.3)\end{array}$ & $\begin{array}{l}63.9 \\
(58.2 \text { to } \\
69.7)\end{array}$ & $\begin{array}{l}51.0 \\
(36.1 \text { to } \\
65.9)\end{array}$ & $\begin{array}{l}21.5 \\
(11.5 \text { to } \\
31.6)\end{array}$ & $\begin{array}{l}30.5 \\
(18.2 \text { to } \\
42.8)\end{array}$ & $\begin{array}{l}42.4 \\
(24.8 \text { to } \\
60.0)\end{array}$ & 0.173 \\
\hline $\begin{array}{l}\text { Non-Hispanic } \\
\text { white }\end{array}$ & $\begin{array}{l}28.2 \\
(18.3 \text { to } \\
38.0)\end{array}$ & $\begin{array}{l}57.4 \\
(32.0 \text { to } \\
82.8)\end{array}$ & $\begin{array}{l}58.8 \\
(37.3 \text { to } \\
80.2)\end{array}$ & $\begin{array}{l}40.1 \\
(20.2 \text { to } \\
60.1)\end{array}$ & $\begin{array}{l}49.6 \\
(30.9 \text { to } \\
68.3)\end{array}$ & $\begin{array}{l}48.4 \\
(20.4 \text { to } \\
76.5)\end{array}$ & 0.936 \\
\hline $\begin{array}{l}\text { Non-Hispanic } \\
\text { black }\end{array}$ & $\begin{array}{l}28.2 \\
(20.9 \text { to } \\
35.5)\end{array}$ & $\begin{array}{l}40.2 \\
(21.1 \text { to } \\
59.3)\end{array}$ & $\begin{array}{l}30.0 \\
(22.2 \text { to } \\
37.9)\end{array}$ & $\begin{array}{l}51.1 \\
(29.6 \text { to } \\
72.6)\end{array}$ & $\begin{array}{l}71.9 \\
(62.1 \text { to } \\
81.7)\end{array}$ & $\begin{array}{l}44.0 \\
(27.0 \text { to } \\
60.9)\end{array}$ & 0.038 \\
\hline Other & $\begin{array}{l}39.2(6.3 \\
\text { to } 72.1)\end{array}$ & $\begin{array}{l}58.2 \\
(41.4 \text { to } \\
75.0)\end{array}$ & $\begin{array}{l}46.9 \\
(18.4 \text { to } \\
75.4)\end{array}$ & $\begin{array}{l}44.8 \\
(20.9 \text { to } \\
68.7)\end{array}$ & $\begin{array}{l}72.5 \\
(63.0 \text { to } \\
82.0)\end{array}$ & $\begin{array}{l}70.8 \\
(62.7 \text { to } \\
79.0)\end{array}$ & 0.217 \\
\hline
\end{tabular}

apo B, apolipoprotein B. 
Supplementary Table 1 shows the age-adjusted mean levels of apo B and trend in mean levels of apo B. The age-adjusted mean levels of apo $B$ for all adults with diabetes declined from $102 \mathrm{mg} / \mathrm{dL}(95 \% \mathrm{Cl}, 95$ to $110 \mathrm{mg} / \mathrm{dL})$ in $2005-2006$ to $95 \mathrm{mg} / \mathrm{dL}(95 \% \mathrm{Cl}, 88$ to $102 \mathrm{mg} / \mathrm{dL})$ in $2015-2016$ ( $\beta,-0.90 \mathrm{mg} / \mathrm{dL}[95 \% \mathrm{Cl}$, -1.90 to $0.10 \mathrm{mg} / \mathrm{dL}$ ] per year), but the linear trend did not reach statistical significance $(P=0.077$ for linear trend) (Supplementary Table 1 and Fig. 1). From 2005 to 2018, a significant linear decreasing trend was observed in the age-adjusted mean non-HDL cholesterol level for all adults with diabetes (from $143 \mathrm{mg} / \mathrm{dL}$ $(95 \% \mathrm{Cl}, 135$ to 151$) \mathrm{mg} / \mathrm{dL}$ in $2005-2006$ to $136 \mathrm{mg} / \mathrm{dL}(95 \% \mathrm{Cl}, 127$ to 144$) \mathrm{mg} / \mathrm{dL}$ in 2017-2018) ( $P=$ 0.004) (Supplementary Table 2 and Fig. 1). The age-adjusted mean LDL cholesterol level for all adults with diabetes was not significantly improved from $107 \mathrm{mg} / \mathrm{dL}(95 \% \mathrm{Cl}, 96$ to 117) $\mathrm{mg} / \mathrm{dL}$ in 2005-2006 to $105 \mathrm{mg} / \mathrm{dL}(95 \% \mathrm{Cl}, 98$ to 112$) \mathrm{mg} / \mathrm{dL}$ in 2015-2016 ( $P=0.138$ for linear trend) (Supplementary Table 4 and Fig. 1).

In subgroup analyses by age, sex and race/ethnicity, significant declining trends in age-adjusted mean levels of apo B and non-HDL cholesterol were generally observed for patients aged 60 years or older, for Mexican Americans, and for non-Hispanic blacks. Also, a declining trend in mean non-HDL cholesterol level was observed for women $(P=.014)$. No statistically significant declining trends in the age-adjusted mean LDL cholesterol levels were observed for both men and women, all race/ethnicity subgroups, and every age group except for patients aged 60 years or older.

\section{Age-adjusted Trends In Geometric Mean Concentrations Of A1c}

From 2005 to 2018, the age-adjusted geometric mean concentration of A1C was not significantly reduced for all adults with diabetes from $7.3 \%(95 \% \mathrm{Cl}, 6.9-7.7 \%)$ in $2005-2006$ to $7.1 \%(95 \% \mathrm{Cl}, 6.7-7.5 \%)$ in 2017-2018, and the linear trend was not statistically significant $(P=0.202$ for linear trend) (Supplementary Table 6). Also, there is no statistically significant change in the age-adjusted geometric mean concentrations of A1C for every age group, both men and women, and all race/ethnicity subgroups.

\section{Age-Adjusted Trends in the Percentage of Participants Meeting Apo B, Non-HDL Cholesterol, and LDL Cholesterol Goals}

The age-adjusted percentage of participants with diagnosed diabetes who had a level of apo $\mathrm{B}<90 \mathrm{mg} / \mathrm{dL}$ increased from $28.8 \%(95 \% \mathrm{Cl}, 20.0-37.6 \%)$ in $2005-2006$ to $47.3 \%(95 \% \mathrm{Cl}, 33.7-60.8 \%)$ in $2015-2016$, but the linear trend was not statistically significant $(P=0.184)$ (Table 2 and Supplementary Fig. 1). From 2005 to 2018, there was an increasing linear trend in the age-adjusted percentage of patients who achieved the non-HDL cholesterol goal of levels $<130 \mathrm{mg} / \mathrm{dL}$ for all adults with diabetes, from $42.4 \%(95 \% \mathrm{Cl}, 31.2-$ $53.7 \%)$ in $2005-2006$ to $54.2 \%(95 \% \mathrm{Cl}, 45.7-62.7 \%)$ in $2017-2018$, but the trend were also not significant $(P=0.098)$ (Supplementary Table 3 and Supplementary Fig. 1). From 2005 to 2016, the age-adjusted 
proportion of patients who achieved the LDL cholesterol goal of levels $<100 \mathrm{mg} / \mathrm{dL}$ did not significantly increase in all adults with diabetes $(P=0.379)$ (Supplementary Table 4 and Supplementary Fig. 1).

In subgroup analyses by age, sex and race/ethnicity, a linear increase was observed in the age-adjusted proportion of all adults with diabetes who achieved the apo B goal of levels $<90 \mathrm{mg} / \mathrm{dL}$ or the non-HDL Cholesterol goal of levels $<130 \mathrm{mg} / \mathrm{dL}$ among women but not among men. The increase in the ageadjusted proportion of all adults with diabetes who had the apo B goal of levels $<90 \mathrm{mg} / \mathrm{dL}$ was observed for patients aged 20 to 39 years $(P=0.044)$ and for non-Hispanic blacks $(P=0.038)$. The age-adjusted proportion of patients meeting the non-HDL cholesterol goal of levels $<130 \mathrm{mg} / \mathrm{dL}$ increased significantly for those aged 60 years or older $(P=0.031)$, and for Mexican Americans $(P=0.029)$. The age-adjusted proportion of patients meeting the LDL cholesterol goal of levels $<100 \mathrm{mg} / \mathrm{dL}$ did not significantly increase for every age group, both sexes, and every racial/ethnic group.

Furthermore, the age-adjusted percentage of participants with diagnosed diabetes who met the more aggressive apo B goal of levels $<80 \mathrm{mg} / \mathrm{dL}$ was $33.6 \%$ (95\% Cl, 18.7-48.5\%) in 2015-2016. The ageadjusted percentage of patients who achieved the more aggressive LDL cholesterol goal of levels < $70 \mathrm{mg} / \mathrm{dl}$ was $10.9 \%$ (95\% Cl, 7.7-14.1\%) in 2015-2016. The age-adjusted percentage of patients who achieved the more aggressive non-HDL cholesterol goal of levels $<100 \mathrm{mg} / \mathrm{dl}$ was $23.0 \%(95 \% \mathrm{Cl}, 14.7-$ $31.4 \%)$ in 2017-2018.

\section{Age-Adjusted Trends in the Percentage of Participants Achieving Glycemic Goals or Showing Poor Glycemic Control}

From 2005 to 2018, the age-adjusted percentage of adults with diabetes who achieved the A1C target concentration of $<7 \%$ increase from $53.1 \%(95 \% \mathrm{Cl}, 44.7-61.5 \%)$ in $2005-2006$ to $55.3 \%(95 \% \mathrm{Cl}, 41.8-$ $68.8 \%$ ) in 2017-2018, but the change was not statistically significant $(P=0.275)$ (Table 3 and

Supplementary Fig. 2). Also, the age-adjusted percentage of participants showing poor glycemic control for adults with diabetes improved slightly from $23.2 \%(95 \% \mathrm{Cl}, 15.9-30.4 \%)$ in $2005-2006$ to $16.1 \%(95 \% \mathrm{Cl}$, 9.4-22.7\%) in 2017-2018, but there were no statistically significance $(P=0.996)$ (Supplementary Table 7 and Supplementary Fig. 2). 
Table 3

Age-adjusted percentage of achieving hemoglobin A 1c concentration $<7 \%$ among U.S. adults with diabetes aged $\geq 20$ years, $2005-2018$

\begin{tabular}{|c|c|c|c|c|c|c|c|c|}
\hline & $\begin{array}{l}2005- \\
2006\end{array}$ & $\begin{array}{l}2007- \\
2008\end{array}$ & $\begin{array}{l}2009- \\
2010\end{array}$ & $\begin{array}{l}2011- \\
2012\end{array}$ & $\begin{array}{l}2013- \\
2014\end{array}$ & $\begin{array}{l}2015- \\
2016\end{array}$ & $\begin{array}{l}2017- \\
2018\end{array}$ & $\begin{array}{l}P \text { for } \\
\text { linear }\end{array}$ \\
\hline & $\begin{array}{l}\mathrm{A} 1 \mathrm{C}< \\
7 \%\end{array}$ & $\begin{array}{l}\mathrm{A} 1 \mathrm{C}< \\
7 \%\end{array}$ & $\begin{array}{l}\mathrm{A} 1 \mathrm{C}< \\
7 \%\end{array}$ & $\begin{array}{l}\mathrm{A} 1 \mathrm{C}< \\
7 \%\end{array}$ & $\begin{array}{l}\mathrm{A} 1 \mathrm{C}< \\
7 \%\end{array}$ & $\begin{array}{l}\mathrm{A} 1 \mathrm{C}< \\
7 \%\end{array}$ & $\begin{array}{l}\mathrm{A} 1 \mathrm{C}< \\
7 \%\end{array}$ & \\
\hline Total & $\begin{array}{l}53.1 \\
(44.7 \text { to } \\
61.5)\end{array}$ & $\begin{array}{l}53.4 \\
(42.5 \text { to } \\
64.3)\end{array}$ & $\begin{array}{l}51.0 \\
(39.0 \text { to } \\
63.0)\end{array}$ & $\begin{array}{l}51.5 \\
(41.4 \text { to } \\
61.7)\end{array}$ & $\begin{array}{l}49.1 \\
(40.9 \text { to } \\
57.4)\end{array}$ & $\begin{array}{l}57.6 \\
(51.7 \text { to } \\
63.4)\end{array}$ & $\begin{array}{l}55.3 \\
(41.8 \text { to } \\
68.8)\end{array}$ & 0.275 \\
\hline Age group, y & & & & & & & & \\
\hline $20-39$ & $\begin{array}{l}46.7 \\
(27.8 \text { to } \\
65.7)\end{array}$ & $\begin{array}{l}52.6 \\
(30.3 \text { to } \\
75.0)\end{array}$ & $\begin{array}{l}48.5 \\
(24.2 \text { to } \\
72.7)\end{array}$ & $\begin{array}{l}48.2 \\
(22.9 \text { to } \\
73.5)\end{array}$ & $\begin{array}{l}50.1 \\
(33.0 \text { to } \\
67.3)\end{array}$ & $\begin{array}{l}70.3 \\
(60.7 \text { to } \\
80.0)\end{array}$ & $\begin{array}{l}62.6 \\
(35.4 \text { to } \\
89.7)\end{array}$ & 0.136 \\
\hline $40-59$ & $\begin{array}{l}52.4 \\
(39.5 \text { to } \\
65.2)\end{array}$ & $\begin{array}{l}53.8 \\
(43.2 \text { to } \\
64.5)\end{array}$ & $\begin{array}{l}49.9 \\
(36.7 \text { to } \\
63.0)\end{array}$ & $\begin{array}{l}50.8 \\
(40.1 \text { to } \\
61.5)\end{array}$ & $\begin{array}{l}43.3 \\
(34.4 \text { to } \\
52.1)\end{array}$ & $\begin{array}{l}44.4 \\
(33.8 \text { to } \\
55.1)\end{array}$ & $\begin{array}{l}46.4 \\
(34.2 \text { to } \\
58.6)\end{array}$ & 0.113 \\
\hline$\geq 60$ & $\begin{array}{l}65.2 \\
(53.8 \text { to } \\
76.6)\end{array}$ & $\begin{array}{l}54.1 \\
(46.5 \text { to } \\
61.6)\end{array}$ & $\begin{array}{l}57.2 \\
(50.2 \text { to } \\
64.2)\end{array}$ & $\begin{array}{l}58.4 \\
(49.3 \text { to } \\
67.4)\end{array}$ & $\begin{array}{l}56.8 \\
(47.2 \text { to } \\
66.4)\end{array}$ & $\begin{array}{l}56.8 \\
(48.7 \text { to } \\
64.8)\end{array}$ & $\begin{array}{l}56.9 \\
(47.3 \text { to } \\
66.5)\end{array}$ & 0.423 \\
\hline Sex & & & & & & & & \\
\hline Male & $\begin{array}{l}47.8 \\
(34.8 \text { to } \\
60.8)\end{array}$ & $\begin{array}{l}49.4 \\
(36.3 \text { to } \\
62.5)\end{array}$ & $\begin{array}{l}45.4 \\
(29.2 \text { to } \\
61.6)\end{array}$ & $\begin{array}{l}49.4 \\
(36.1 \text { to } \\
62.7)\end{array}$ & $\begin{array}{l}50.4 \\
(38.1 \text { to } \\
62.6)\end{array}$ & $\begin{array}{l}48.6 \\
(35.6 \text { to } \\
61.7)\end{array}$ & $\begin{array}{l}54.6 \\
(40.2 \text { to } \\
69.0)\end{array}$ & 0.124 \\
\hline Female & $\begin{array}{l}57.7 \\
(47.1 \text { to } \\
68.2)\end{array}$ & $\begin{array}{l}56.4 \\
(44.4 \text { to } \\
68.4)\end{array}$ & $\begin{array}{l}58.3 \\
(42.8 \text { to } \\
73.7)\end{array}$ & $\begin{array}{l}53.5 \\
(37.3 \text { to } \\
69.8)\end{array}$ & $\begin{array}{l}49.9 \\
(37.0 \text { to } \\
62.7)\end{array}$ & $\begin{array}{l}63.9 \\
(58.7 \text { to } \\
69.1)\end{array}$ & $\begin{array}{l}58.8 \\
(42.3 \text { to } \\
75.3)\end{array}$ & 0.838 \\
\hline Race/ethnicity & & & & & & & & \\
\hline $\begin{array}{l}\text { Mexican } \\
\text { American }\end{array}$ & $\begin{array}{l}54.8 \\
(35.1 \text { to } \\
74.5)\end{array}$ & $\begin{array}{l}48.4 \\
(32.9 \text { to } \\
63.8)\end{array}$ & $\begin{array}{l}44.7 \\
(23.8 \text { to } \\
65.5)\end{array}$ & $\begin{array}{l}26.2 \\
(16.1 \text { to } \\
36.2)\end{array}$ & $\begin{array}{l}48.5 \\
(30.2 \text { to } \\
66.8)\end{array}$ & $\begin{array}{l}33.1 \\
(19.1 \text { to } \\
47.1)\end{array}$ & $\begin{array}{l}50.5 \\
(32.8 \text { to } \\
68.2)\end{array}$ & 0.824 \\
\hline $\begin{array}{l}\text { Non-Hispanic } \\
\text { white }\end{array}$ & $\begin{array}{l}49.3 \\
(36.0 \text { to } \\
62.7)\end{array}$ & $\begin{array}{l}52.2 \\
(37.5 \text { to } \\
67.0)\end{array}$ & $\begin{array}{l}53.6 \\
(37.7 \text { to } \\
69.5)\end{array}$ & $\begin{array}{l}59.2 \\
(42.5 \text { to } \\
75.8)\end{array}$ & $\begin{array}{l}47.6 \\
(36.9 \text { to } \\
58.3)\end{array}$ & $\begin{array}{l}70.8 \\
(61.9 \text { to } \\
79.6)\end{array}$ & $\begin{array}{l}55.3 \\
(31.3 \text { to } \\
79.4)\end{array}$ & 0.414 \\
\hline $\begin{array}{l}\text { Non-Hispanic } \\
\text { black }\end{array}$ & $\begin{array}{l}43.9 \\
(32.5 \text { to } \\
55.2)\end{array}$ & $\begin{array}{l}54.1 \\
(36.5 \text { to } \\
71.8)\end{array}$ & $\begin{array}{l}46.9 \\
(26.2 \text { to } \\
67.7)\end{array}$ & $\begin{array}{l}50.1 \\
(31.8 \text { to } \\
68.4)\end{array}$ & $\begin{array}{l}52.0 \\
(39.5 \text { to } \\
64.5)\end{array}$ & $\begin{array}{l}46.6 \\
(39.4 \text { to } \\
53.8)\end{array}$ & $\begin{array}{l}50.6 \\
(35.4 \text { to } \\
65.7)\end{array}$ & 0.961 \\
\hline Other & $\begin{array}{l}64.6 \\
(36.6 \text { to } \\
92.5)\end{array}$ & $\begin{array}{l}76.0 \\
(65.5 \text { to } \\
86.5)\end{array}$ & $\begin{array}{l}46.8 \\
(24.6 \text { to } \\
69.1)\end{array}$ & $\begin{array}{l}46.5 \\
(33.3 \text { to } \\
59.7)\end{array}$ & $\begin{array}{l}51.8 \\
(32.1 \text { to } \\
71.5)\end{array}$ & $\begin{array}{l}65.7 \\
(56.0 \text { to } \\
75.4)\end{array}$ & $\begin{array}{l}70.4 \\
(65.3 \text { to } \\
75.4)\end{array}$ & 0.351 \\
\hline
\end{tabular}

In the subgroup analyses, the proportion of patients who achieved the A1C goals of $<7 \%$ was not statistically significant changes over the 14 -year period for every age group, both men and women, and all 
race/ethnicity subgroups. Similar trends over this 14-year period were observed in the proportion of those who achieved the A1C of $>9 \%$.

\section{Age-Adjusted Trends in the Percentage of Participants Achieving All Three Lipids Goals and the Glycemic Goal}

Among all adults with diagnosed diabetes, the percentages of patients who achieved the apo B goal of < $90 \mathrm{mg} / \mathrm{dL}$, the non-HDL cholesterol goal of $<130 \mathrm{mg} / \mathrm{dl}$, the LDL cholesterol goal of $<100 \mathrm{mg} / \mathrm{dl}$, and the A1C target of $<7 \%$ increased from $15.2 \%(95 \% \mathrm{Cl}, 7.4-23.0 \%)$ in $2005-2006$ to $30.6 \%(95 \% \mathrm{Cl}, 18.1-43.1 \%)$ in 2015-2016, but the trend was not reach statistically significant $(P<0.396)$ (Supplementary Table 8 and Supplementary Fig. 2).

In the subgroup analyses, Mexican Americans and non-Hispanic blacks were less likely to meet all four goals than non-Hispanic whites, and men were less likely to achieve all four goals than women.

The proportion of all diabetic adults with at least one optimal level-either for apo B, non-HDL cholesterol, LDL cholesterol, or A1C-increased from $66.9 \%(95 \% \mathrm{Cl}, 55.4-78.5 \%)$ in $2005-2006$ to $73.3 \%(95 \% \mathrm{Cl}$, $65.4-81.1 \%)$ in $2015-2016$, but the trend was also not statistically significant $(P<0.996)$.

We also found that the percentages of patients who were achieving all of the more aggressive goals (i.e., apo $\mathrm{B}<80 \mathrm{mg} / \mathrm{dL}$, non-HDL cholesterol $<100 \mathrm{mg} / \mathrm{dl}$, LDL cholesterol $<70 \mathrm{mg} / \mathrm{dl}$, and $\mathrm{A} 1 \mathrm{C}<7 \%$ ) was $3.9 \%$ $(95 \% \mathrm{Cl}, 1.8-5.9 \%)$ in $2015-2016$.

\section{Discussion}

Among all adults with diabetes, significant declining trend in age-adjusted mean level of non-HDL cholesterol was observed from 2005 to 2018. No statistically significant decline in age-adjusted mean level of apo B was found from 2005 to 2016. Furthermore, the age-adjusted mean LDL cholesterol level and geometric mean A1C concentrations did not improve significantly. Significant declining trends in ageadjusted mean levels of apo B, non-HDL cholesterol, and LDL cholesterol were overall observed for patients aged 60 years or older. The increases observed in the percentages of patients who achieved the apo B goal of level $<90 \mathrm{mg} / \mathrm{dL}$, the non-HDL cholesterol goal of level $<130 \mathrm{mg} / \mathrm{dL}$, or the LDL cholesterol goal of level $<100 \mathrm{mg} / \mathrm{dL}$ but were not statistically significant. In addition, the age-adjusted percentage of those achieving the A1C target concentration of $<7 \%$ did not increase significantly from 2005 to 2018, and the age-adjusted percentage of adults with diabetes showing poor glycemic control (A1C > $\%$ ) remained high (16.1\%) in 2017-2018. The percentages of patients achieving all four goals was $30.6 \%(95 \% \mathrm{Cl}, 18.1-$ 43.1\%) in 2015-2016, and, compared with non-Hispanic whites, Mexican Americans and non-Hispanic blacks were less likely to achieve all four goals.

Some studies have indicated that individuals with diagnosed diabetes may alter their lifestyles to improve their glycemic control and lipid profiles through such steps as healthy eating, smoking cessation, weight management, and/or physical activity. In a previous study using a national sample of subjects with diabetes, most participants tried increase their physical activity, lose weight, and change their diet [27]. 
There is evidence that diet for reducing cholesterol concentration achieved a greater reduction in serum cholesterol concentration [28]. We found that the observed declines in the mean apo B levels were of relatively smaller magnitude and the mean non-HDL cholesterol levels declined significantly. The percentages of patients achieving the apo B goal of levels $<90 \mathrm{mg} / \mathrm{dL}$, the non-HDL cholesterol goal of levels $<130 \mathrm{mg} / \mathrm{dl}$, the LDL cholesterol goal of levels $<100 \mathrm{mg} / \mathrm{dl}$, and the A1C target of concentrations < $7 \%$ increased from $15.2 \%$ in $2005-2006$ to $30.6 \%$ in $2015-2016$, although the results were not statistically significant. Several studies have shown that increased physical activity can prevent or delay the development of type 2 diabetes [29] and improve cardiovascular risk factors in persons with type 2 diabetes [30].

The increasing use of lipid-lowering medications may also have contributed to the observed improvements in patients' lipid profiles. A cohort study found that statin use has increased substantially among US adults in recent years, from $17.9 \%$ in $2002-2003$ to $27.8 \%$ in $2012-2013$ [31].

Some studies have found significant improvements in measures of 10-year coronary heart disease risk among adults with diabetes over the past decade [32] and reduced morbidity and mortality associated with atherosclerotic cardiovascular disease [33]. Because hypertriglyceridemia is commonly seen in individuals with diabetes, the measurement and monitoring of apolipoprotein levels have been recommended as a guide for lipid-lowering therapies [34, 35]. There is substantial evidence that, compared with LDL cholesterol, apo B is a superior marker of vascular disease, and non-HDL cholesterol is a better predictor of risk for cardiovascular disease. In the present study, we also estimated the percentages of patients who were achieving the more aggressive all lipid goals and found that few achieved the more aggressive target of lipid control. At the end of the study period, $33.6 \%$ had achieved the more aggressive apo B goal of levels $<80 \mathrm{mg} / \mathrm{dL}, 23.0 \%$ had achieved the more aggressive non-HDL cholesterol goal of levels $<100 \mathrm{mg} / \mathrm{dl}$, and only $10.9 \%$ had achieved the more aggressive LDL cholesterol goal of levels $<70 \mathrm{mg} / \mathrm{dl}$. Among patients who achieved the $\mathrm{A} 1 \mathrm{C}$ target of concentration $<7 \%$, only $3.9 \%$ achieved the more aggressive all three lipid goals just listed. Nonpharmacological correlates of serum lipid levels and use of medications may jointly influence the observed patterns.

For adults with diabetes, adherence to self-care recommendations naturally promotes overall diabetes control. A cross-sectional study of 476 type 2 diabetic patients found that good adherence to an appropriate diet was associated with a favorable serum lipid profile and that a relatively low BMI was associated with physical activity [36]. The present study showed that, compared with those of patients aged 60 years or older, the mean apo B, non-HDL cholesterol, and LDL cholesterol levels of young and middle-aged adults was higher and the proportion of patients who achieved the goals for apo B, non-HDL cholesterol, or LDL cholesterol was smaller. This result may indicate that older adults with diabetes tend to adhere better to lifestyle and/or medication therapy than younger adults. Also, it could be that older adults have been exposed more to the healthcare system than younger patients, and thus the cumulative effect of health interventions in older versus younger patients led to this particular result.

Moreover, the target for most adults with diabetes is an $\mathrm{A} 1 \mathrm{C}$ concentration of less than $7 \%$. Our findings indicated that Mexican Americans and non-Hispanic blacks tended to have higher A1C concentrations and 
poorer glycemic control than non-Hispanic whites and were less likely to meet all four goals. The racial disparities in glycemic control are consistent with previous findings [19,37]. Future research should explore factors that contributed to reducing the ethnic disparities and focus on interventions to eliminate disparities.

In the present study, poor glycemic control was more common in younger than older subjects and in men than in women. Previous studies also found that younger individuals were less likely to achieve their A1C goals [13]. Diabetes medication adherence has been associated with reduced A1C concentrations in the middle-aged to elderly type 2 diabetes patients [36]. Women may tend to demonstrate better adherence than men; a cross-sectional study of 6729 subjects found that the proportion of male diabetes patients adhering to regular treatment was low [38].

\section{Strengths And Limitations}

The strengths of this study include the use of a nationally representative sample, which makes it possible to draw generalizations about the U.S. adult population. The measurement of levels of apolipoprotein $B$, total cholesterol, $\mathrm{HDL}$ cholesterol, triglyceride and A1C were based on the criteria of the CDC's standardization program. This study also had some limitations. To begin with, individuals with diagnosed diabetes in the sample were the small number. Owing to limitations in power, subgroup analyses must be interpreted with caution. Participants in the fasting sample was limited, which lead to LDL estimates unreliable. Further, our analysis of trends in lipids levels and A1C concentration among adults was based on 6 or 7 NHANES survey periods, so data from future surveys are needed to further confirm our results.

\section{Conclusions}

This study found a significant declining trend in mean non-HDL cholesterol level for all adults with diabetes from 2005 to 2018 and no statistically significant decline in level of apo B from 2005 to 2016. The observed increases in the proportion of the diabetes patients who were achieving the apo B, non-HDL cholesterol, LDL cholesterol, or A1C goals were also not statistically significant. The proportion of poor glycemic control for adults with diagnosed diabetes remained high in 2017-2018. A significant opportunity exists to improve glycemic and lipid profiles further and, thus, to decrease diabetes-related complications.

\section{Abbreviations}

A1C: hemoglobin A1c; apo B: apolipoprotein B; CDC: Centers for Disease Control and Prevention; Cl: confidence interval; HR: hazards ratio; LDL: low-density lipoprotein; NCHS: National Center for Health Statistics; NHANES: National Health and Nutrition Examination Survey; non-HDL: non-high-density lipoprotein; OR: odds ratio.

\section{Declarations}


The study protocol of NHANES was approved by the research ethics review board of the National Center for Health Statistics (NCHS) of the Centers for Disease Control and Prevention (CDC). Written informed consent was provided from all of the participants in the NHANES.

\section{Consent for publication}

Not applicable.

\section{Availability of data and materials}

Use of a Public Data.

\section{Competing interests}

The authors declare that there is no conflict of interest that could be perceived as prejudicing the impartiality of this study.

\section{Funding}

This work was funded by National Natural Science Foundation (NSFC 81973065) of China. The sponsors played no role in the design of the study; in the collection, analysis, or interpretation of the data; or in the preparation or approval of the manuscript.

\section{Authors' contributions}

XW and DZ contributed to the study concept and design, collected and analyzed data, contributed to discussion, and wrote, reviewed, and edited the manuscript. YD and YBS designed the study, collected and analyzed data, and contributed to discussion. LGS contributed to discussion and reviewed and edited the manuscript. All authors approved of the final version.

\section{Acknowledgements}

The authors acknowledge the contributions of the CDC recognized organizations that collected and submitted the data used in this study.

\section{Authors' information (optional)}

Department of Maternal and Child Health, School of Public Health, Cheeloo College of Medicine, Shandong University, Jinan, China (Xia Wang and Di Zhu). Department of Epidemiology, University of lowa College of Public Health, lowa City, United States (Yang Du and Linda G Snetselaar). Department of Preventive Medicine, The University of Tennessee Health Science Center, Memphis, Tennessee, United States (YangBo Sun).

\section{References}


1. Roglic G, Unwin N, Bennett PH, Mathers C, Tuomilehto J, Nag S, et al. The burden of mortality attributable to diabetes: realistic estimates for the year 2000. Diabetes Care. 2005;28:2130-5.

2. Harper CR, Jacobson TA. Using apolipoprotein B to manage dyslipidemic patients: time for a change? In: Mayo Clinic Proceedings; 2010: Mayo Foundation; 2010. p. 440.

3. Wägner AM, Pérez A, Zapico E, Ordóñez-Llanos J. Non-HDL cholesterol and apolipoprotein B in the dyslipidemic classification of type 2 diabetic patients. Diabetes Care. 2003;26:2048-51.

4. Vega GL, Grundy SM. Does measurement of apolipoprotein B have a place in cholesterol management? Arteriosclerosis: An Official Journal of the American Heart Association Inc. 1990;10:668-71.

5. Jiang R, Schulze MB, Li T, Rifai N, Stampfer MJ, Rimm EB, et al. Non-HDL cholesterol and apolipoprotein $B$ predict cardiovascular disease events among men with type 2 diabetes. Diabetes Care. 2004;27:1991-7.

6. Sathiyakumar V, Park J, Quispe R, Elshazly MB, Michos ED, Banach M, et al. Impact of novel lowdensity lipoprotein-cholesterol assessment on the utility of secondary non-high-density lipoprotein-C and apolipoprotein B targets in selected worldwide dyslipidemia guidelines. Circulation. 2018;138:244-54.

7. Sniderman AD, Williams K, Contois JH, Monroe HM, McQueen MJ, de Graaf J, et al. A meta-analysis of low-density lipoprotein cholesterol, non-high-density lipoprotein cholesterol, and apolipoprotein B as markers of cardiovascular risk. Circ Cardiovasc Qual Outcomes. 2011;4:337-45.

8. Cui Y, Blumenthal RS, Flaws JA, Whiteman MK, Langenberg P, Bachorik PS, et al. Non-high-density lipoprotein cholesterol level as a predictor of cardiovascular disease mortality. Arch Intern Med. 2001;161:1413-9.

9. Frost PH, Havel RJ. Rationale for use of non-high-density lipoprotein cholesterol rather than lowdensity lipoprotein cholesterol as a tool for lipoprotein cholesterol screening and assessment of risk and therapy. Am J Cardiol. 1998;81:26B-31B.

10. Ramjee V, Sperling LS, Jacobson TA. Non-high-density lipoprotein cholesterol versus apolipoprotein B in cardiovascular risk stratification: do the math. J Am Coll Cardiol. 2011;58:457-63.

11. Jellinger PS. American Association of Clinical Endocrinologists/American College of Endocrinology Management of dyslipidemia and prevention of cardiovascular disease clinical practice guidelines. Diabetes Spectr. 2018;31:234-45.

12. Garber AJ, Abrahamson MJ, Barzilay JI, Blonde L, Bloomgarden ZT, Bush MA, et al. Consensus statement by the American Association of Clinical Endocrinologists and American College of Endocrinology on the comprehensive type 2 diabetes management algorithm-2018 executive summary. Endocr Pract. 2018;24:91-120.

13. Casagrande SS, Fradkin JE, Saydah SH, Rust KF, Cowie CC. The prevalence of meeting A1C, blood pressure, and LDL goals among people with diabetes, 1988-2010. Diabetes Care. 2013;36:2271-9.

14. Ford ES, Li C, Sniderman A. Temporal changes in concentrations of lipids and apolipoprotein B among adults with diagnosed and undiagnosed diabetes, prediabetes, and normoglycemia: findings from the 
National Health and Nutrition Examination Survey 1988-1991 to 2005-2008. Cardiovasc Diabetol. 2013;12:26.

15. Carroll MD, Mussolino ME, Wolz M, Srinivas PR. Trends in Apolipoprotein B, Non-High-Density Lipoprotein, and Low-Density Lipoprotein for Adults 60 Years and Older by Use of Lipid-Lowering Medications: United States, 2005 to 2006 Through 2013 to 2014. Circulation. 2018;138:208-10.

16. Hird TR, Pirie FJ, Esterhuizen TM, O’Leary B, McCarthy MI, Young EH, et al. Burden of diabetes and first evidence for the utility of $\mathrm{HbA} 1 \mathrm{c}$ for diagnosis and detection of diabetes in urban black South Africans: The Durban Diabetes Study. PLoS One. 2016;11:e0161966.

17. Florkowski C. HbA1c as a diagnostic test for diabetes mellitus-reviewing the evidence. Clin Biochem Rev. 2013;34:75.

18. Association AD. 6. Glycemic Targets: Standards of Medical Care in Diabetes-2020. Diabetes Care. 2020;43:66.

19. Ford ES, Li C, Little RR, Mokdad AH. Trends in A1C concentrations among US adults with diagnosed diabetes from 1999 to 2004. Diabetes Care. 2008;31:102-4.

20. Harris MI, Eastman RC, Cowie CC, Flegal KM, Eberhardt MS. Racial and ethnic differences in glycemic control of adults with type 2 diabetes. Diabetes Care. 1999;22:403-8.

21. Prevention CfDCa. About the National Health and Nutrition Examination Survey. https://www.cdc.gov/nchs/nhanes/about_nhanes.htm.Accessed June 2, 2019.

22. Prevention CfDCa. National Health and Nutrition Examination Survey response rates and population totals. https://wwwn.cdc.gov/nchs/nhanes/ResponseRates.aspx.

23. Accessed June 2, 2019.

24. Prevention CfDCa. NHANES laboratory data. 2017 Accessed at wwwn.cdc.gov/nchs/nhanes/search/datapage.aspx?Component = Laboratory.on 24 February 2017.

25. Centers for Disease Control and Prevention NCfHS. National Health and Nutrition Examination Survey Laboratory Protocol: Cholesterol and Triglycerides. Hyattsville, MD, U.S. Department of Health and Human Services, Centers for Disease Control and Prevention.

26. Friedewald WT, Levy RI, Fredrickson DS. Estimation of the concentration of low-density lipoprotein cholesterol in plasma, without use of the preparative ultracentrifuge. Clin Chem. 1972;18:499-502.

27. Klein RJSC. Age Adjustment Using the 2000 Projected US Population: Healthy People 2010 Statistical Notes. Hyattsville: National Center for Health Statistics.January; 2010.

28. Dorsey R, Songer T. Peer reviewed: lifestyle behaviors and physician advice for change among overweight and obese adults with prediabetes and diabetes in the United States, 2006. Prev Chronic Dis. 2011;8.

29. Tang J, Smith GD, Armitage J, Lancaster T, Silagy C, Fowler G, et al. Systematic review of dietary intervention trials to lower blood total cholesterol in free-living subjectsCommentary: Dietary change, cholesterol reduction, and the public health-what does meta-analysis add? BMJ. 1998;316:1213-20.

30. Bastaki A. Diabetes mellitus and its treatment. International journal of Diabetes Metabolism. 2005;13:111. 
31. Kirk A, Mutrie N, Maclntyre P, Fisher M. Increasing physical activity in people with type 2 diabetes. Diabetes Care. 2003;26:1186-92.

32. Salami JA, Warraich H, Valero-Elizondo J, Spatz ES, Desai NR, Rana JS, et al. National trends in statin use and expenditures in the US adult population from 2002 to 2013: insights from the Medical Expenditure Panel Survey. JAMA Cardiol. 2017;2:56-65.

33. Ali MK, Bullard KM, Saaddine JB, Cowie CC, Imperatore G, Gregg EW. Achievement of goals in US diabetes care, 1999-2010. N Engl J Med. 2013;368:1613-24.

34. Buse J, Ginsberg H, Bakris G, Clark N, Costa F, Eckel R, et al American Heart Association; American Diabetes Association. Primary prevention of cardiovascular diseases in people with diabetes mellitus: a scientific statement from the American Heart Association and the American Diabetes Association. Diabetes Care. 2007;30:162-72.

35. Barter PJ, Ballantyne CM, Carmena R, Cabezas MC, Chapman MJ, Couture P, et al. Apo B versus cholesterol in estimating cardiovascular risk and in guiding therapy: report of the thirty-person/tencountry panel. J Intern Med. 2006;259:247-58.

36. Charlton-Menys V, Betteridge DJ, Colhoun H, Fuller J, France M, Hitman GA, et al. Targets of statin therapy: LDL cholesterol, non-HDL cholesterol, and apolipoprotein B in type 2 diabetes in the Collaborative Atorvastatin Diabetes Study (CARDS). Clin Chem. 2009;55:473-80.

37. Marinho FS, Moram C, Rodrigues PC, Leite NC, Salles GF, Cardoso CR. Treatment adherence and its associated factors in patients with type 2 diabetes: results from the Rio de Janeiro type 2 diabetes cohort study. J Diabetes Res. 2018;2018.

38. Kirk JK, D’Agostino RB, Bell RA, Passmore LV, Bonds DE, Karter AJ, et al. Disparities in HbA1c levels between African-American and non-Hispanic white adults with diabetes: a meta-analysis. Diabetes Care. 2006;29:2130-6.

39. Rodríguez J, Coello S, Pérez CM, Díaz B, Alamo C, Fernández L, et al. Lifestyle and treatment adherence of type 2 diabetes mellitus people in the Canary Islands. Rev Esp Salud Publica. 2009;83:567-75.

\section{Figures}




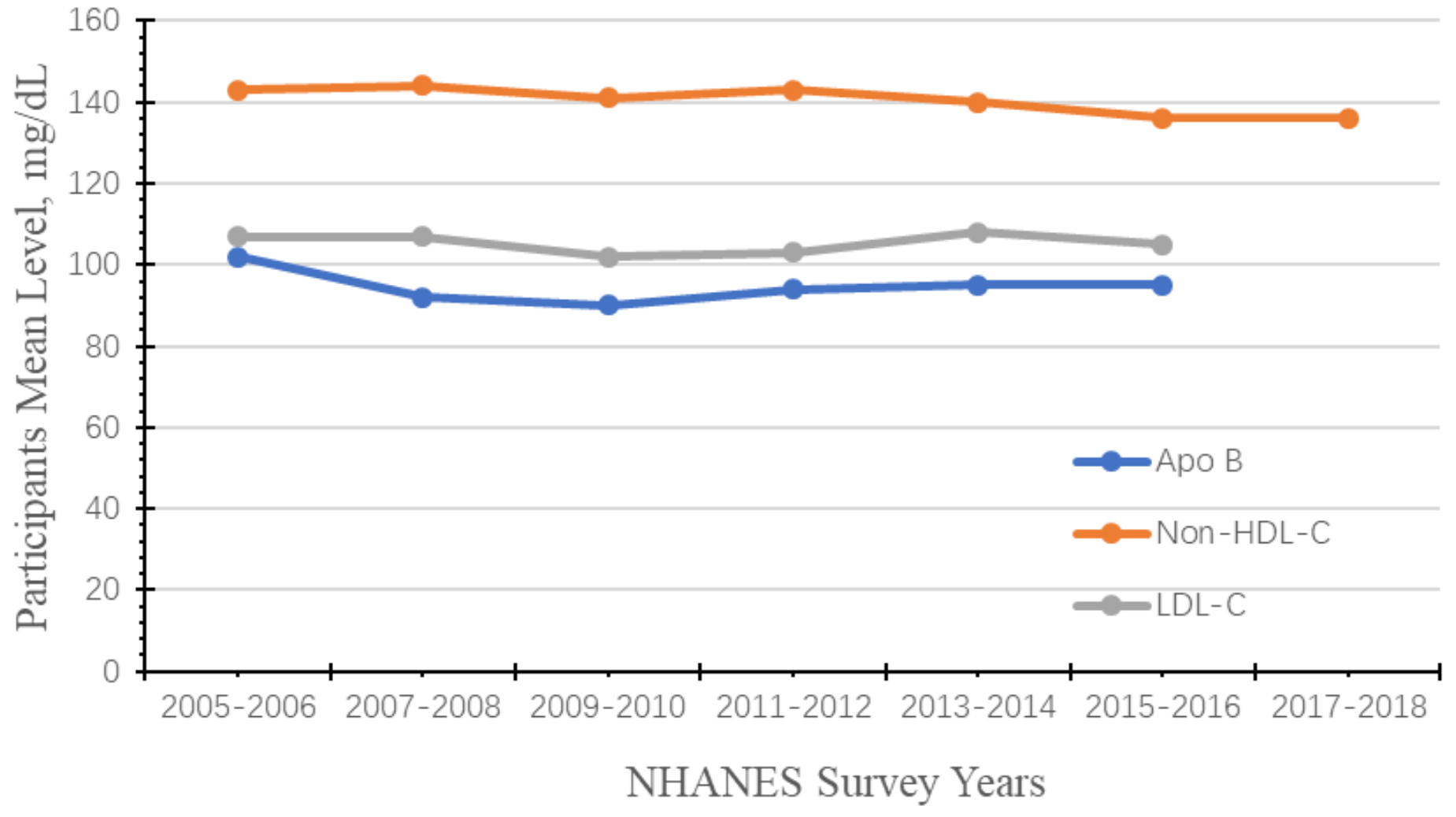

\section{Figure 1}

Age-adjusted in mean levels of apo B, non-HDL cholesterol, and LDL cholesterol among U.S. adults with diabetes aged $\geq 20$ years by NHANES survey cycle from 2005-2006 to 2017-2018. NHANES indicates National Health and Nutrition Examination Survey. Data were adjusted for NHANES survey weights to be nationally representative. 


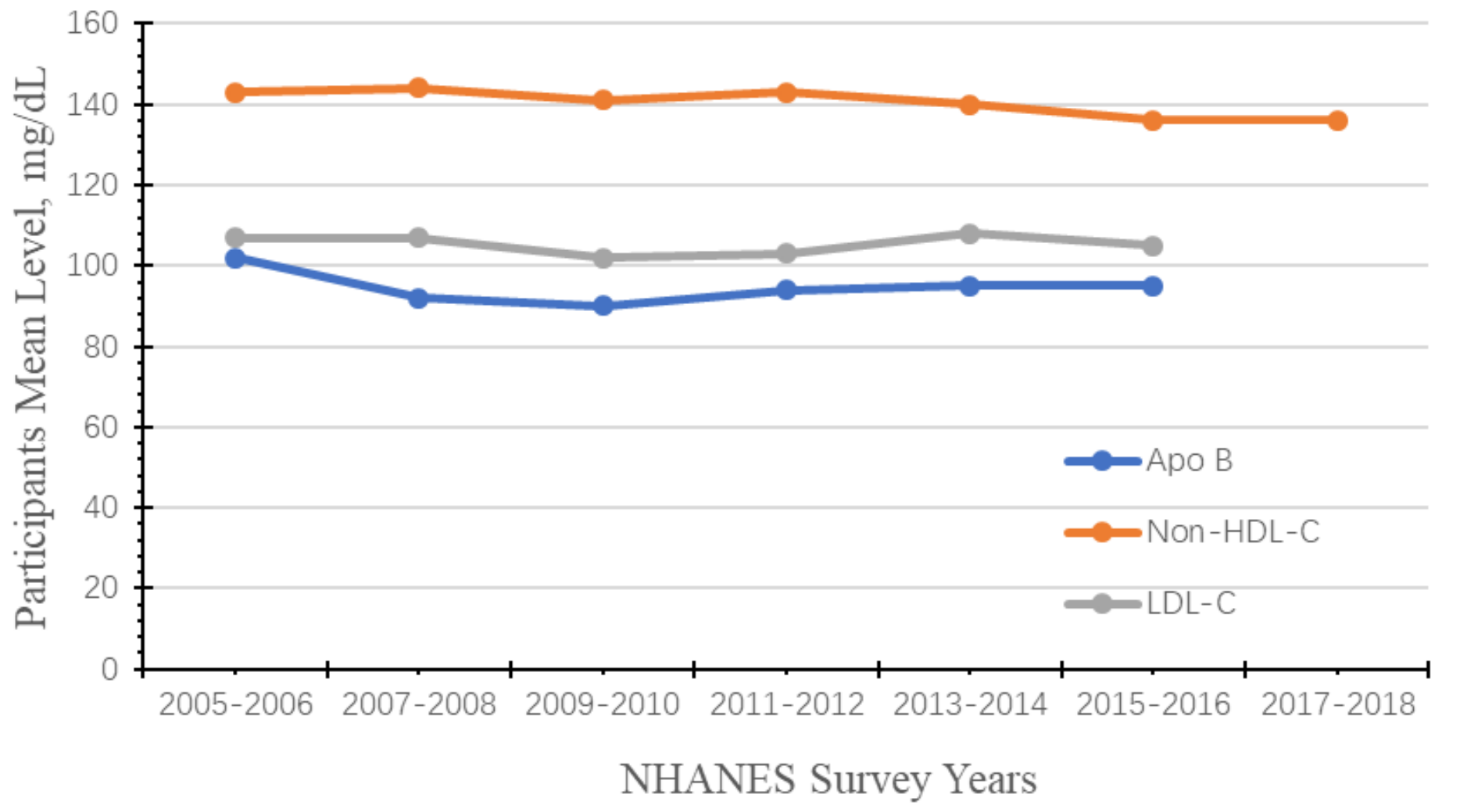

\section{Figure 1}

Age-adjusted in mean levels of apo B, non-HDL cholesterol, and LDL cholesterol among U.S. adults with diabetes aged $\geq 20$ years by NHANES survey cycle from 2005-2006 to 2017-2018. NHANES indicates National Health and Nutrition Examination Survey. Data were adjusted for NHANES survey weights to be nationally representative. 


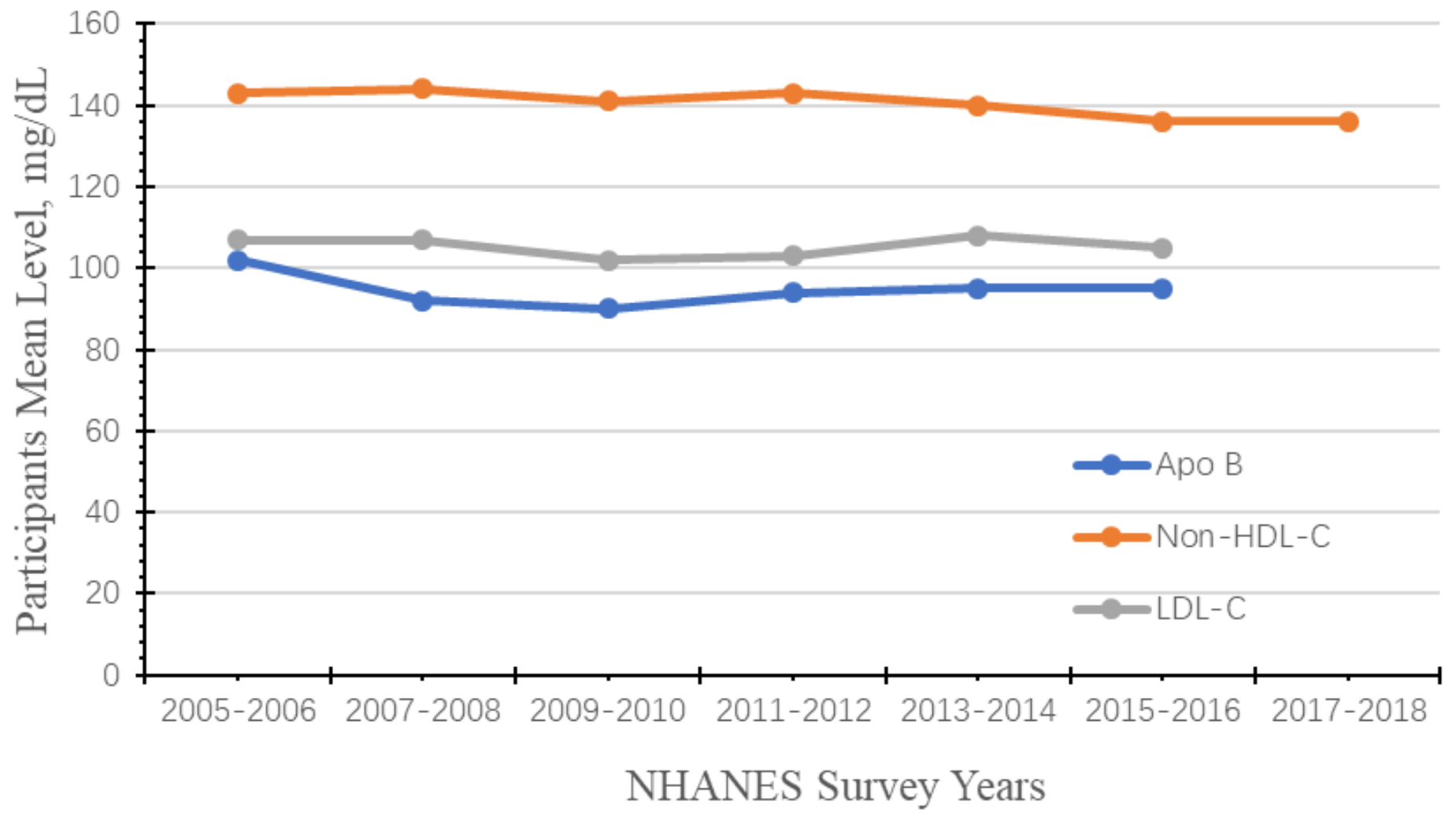

\section{Figure 1}

Age-adjusted in mean levels of apo B, non-HDL cholesterol, and LDL cholesterol among U.S. adults with diabetes aged $\geq 20$ years by NHANES survey cycle from 2005-2006 to 2017-2018. NHANES indicates National Health and Nutrition Examination Survey. Data were adjusted for NHANES survey weights to be nationally representative.

\section{Supplementary Files}

This is a list of supplementary files associated with this preprint. Click to download.

- SupplementaryTablesandFigures.doc

- SupplementaryTablesandFigures.doc

- SupplementaryTablesandFigures.doc 